\title{
Faktor-faktor sosial ekonomi yang mempengaruhi keterlibatan penduduk lanjut usia dalam pasar kerja di Provinsi Jambi
}

\author{
Social and economic factors affecting the involvement of elderly \\ in labor market in Jambi
}

\author{
Junaidi; Erfit; Purwaka Hari Prihanto \\ Fakultas Ekonomi dan Bisnis Universitas Jambi \\ Jalan Raya Jambi Muara-Bulian KM.15 Mendalo Darat Jambi \\ e-mail: junaidi@unja.ac.id
}

\begin{abstract}
The study aims to analyze: 1) individual characteristics and profession of elderly in Jambi province; 2) socioeconomic factors affecting involvement of elderly in labor market. Data used in this study is from "raw data" National Socio-Economic Survey or Survei Sosial Ekonomi Nasionnal (SUSENAS) of Jambi Province in 2015. The results of the study reveals: 1) the number of elderly working is relatively large. Nearly half $(48,99$ percent) of elderly have working as their main activity; 2) the characteristics of elderly who work are: a) predominant in rural areas; b) predominant by men; c) generally has status as the head of the family; d) generally less educated (only graduate from primary school or below); e) mostly working in agricultural with a relatively long working hours; 3) The results of binary logistic regression show that age, sex, education, marital status, status in family, health conditions, and location of rural-urban affect significantly involvement of elderly in labor market.
\end{abstract}

Keywords: labor market, elderly's productivity, health conditions, marital status, agricultural

\begin{abstract}
Abstrak
Penelitian ini bertujuan untuk menganalisis: 1) Karakteristik individu dan pekerjaan penduduk lanjut usia (lansia) yang bekerja di Provinsi Jambi; 2) Faktor-faktor sosial ekonomi yang mempengaruhi keterlibatan penduduk lansia dalam pasar kerja. Data yang digunakan bersumber dari "raw data" Survei Sosial Ekonomi Nasional (SUSENAS) Provinsi Jambi Tahun 2015. Hasil penelitian menemukan: 1) Penduduk lansia yang bekerja di Provinsi Jambi masih relatif besar. Hampir separuh (48,99 persen) dari lansia memiliki kegiatan utama bekerja; 2) Karakteristik lansia bekerja ditandai oleh: a) Lebih dominan di perdesaan; b) Didominasi oleh laki-laki; c) umumnya berstatus kepala keluarga; d) umumnya berpendidikan SD ke bawah; f) sebagian besar bekerja pada lapangan usaha pertanian dengan jam kerja yang relatif panjang; 3) Hasil uji regresi binary logistik menunjukkan bahwa umur, jenis kelamin, pendidikan, status kawin, status dalam keluarga, kondisi kesehatan dan lokasi desa-kota berpengaruh signifikan terhadap keterlibatan penduduk lansia dalam pasar kerja.
\end{abstract}

Kata kunci: pasar kerja, produktivitas lansia, kondisi kesehatan, status perkawinan, pertanian

\section{Pendahuluan}

Struktur penduduk dunia termasuk Indonesia saat ini menuju proses penuaan yang ditandai dengan meningkatnya jumlah dan proporsi penduduk lanjut usia (lansia). Proporsi penduduk lansia (usia 60 tahun ke atas) di Indonesia mengalami peningkatan cukup signifikan. Pada Tahun 1971 proporsi penduduk lanjut usia baru 4,5 persen dari seluruh jumlah penduduk, pada Tahun 2015 meningkat menjadi hampir dua kali lipat yaitu mencapai 8,47 persen (N.N,2016a). Peningkatan jumlah penduduk lansia disebabkan peningkatan angka harapan hidup sebagai dampak dari peningkatan kualitas kesehatan. Pada Tahun 1971 usia harapan hidup Indonesia baru 45,7 tahun menjadi 70,1 tahun pada Tahun 2015 (N.N 2011, N.N 2014).

Secara umum karena faktor usia, lansia akan mengalami berbagai penurunan kondisi dan kemampuan baik secara fisik maupun psikologis. Meskipun demikian, di sisi lain lansia juga dituntut untuk memenuhi kebutuhan hidup sehari-hari, seperti kebutuhan makanan bergizi seimbang, pemeriksaan kesehatan secara rutin, perawatan akibat penyakit penuaan dan kebutuhan rekreasi. Oleh karena itu lansia juga perlu didayagunakan untuk meningkatkan kemandirian agar dapat membantu diri dan keluarganya sehingga tidak lagi menjadi beban bagi orang lain. 
Berdasarkan data Sakernas 2015, dari total lansia di Indonesia, 46,53 persen diantaranya berstatus bekerja. Tingginya persentase lansia yang bekerja pada dasarnya tidak hanya mencerminkan kemampuan lansia untuk tetap bekerja, tetapi di sisi lain juga bisa dimaknai rendahnya tingkat kesejahteraan lansia, sehingga mereka terpaksa masih harus bekerja untuk memenuhi kebutuhan hidupnya (N.N 2016b). Hal ini disebabkan peningkatan yang pesat dalam jumlah dan proporsi penduduk lanjut usia di Indonesia, ternyata tidak diikuti oleh peningkatan yang sama terhadap upaya-upaya jaminan sosial, sehingga banyak lansia dengan segala keterbatasan kondisi fisiknya tetap bekerja. Affandi (2009) mengemukakan tidak sedikit lansia yang masih menghidupi keluarga anaknya yang tinggal bersamanya, karena hidup dalam keluarga yang tidak mampu. Dengan kata lain tanggung jawab sebagai kepala rumah tangga yang sangat besar dari sisi psikologis maupun ekonomis, masih diemban oleh penduduk lansia yang seharusnya menikmati hari tua tanpa beban berat keluarga.

Wirakartakusumah dan Anwar (1994) menyatakan ada tiga alasan yang mempengaruhi lansia bekerja. Pertama, masih banyak lansia yang tetap kuat secara fisik dan mental. Kedua, terjunnya lansia ke pasar kerja karena desakan ekonomi. Ketiga, alasan yang lebih didasarkan pada motif aktualisasi diri atau emosi. Pernyataan ini juga didukung oleh beberapa hasil penelitian yang menunjukkan bahwa keterlibatan lansia dipengaruhi oleh berbagai faktor sosial ekonomi. Faktor sosial ekonomi tersebut mencakup pendidikan, pendapatan keluarga, status dalam keluarga jumlah tanggungan, kesehatan (Affandi 2009, Susilawati et al. 2014, Fitri \& Basri 2012, Kartika \& Sudibia 2014).

Sebagai salah satu daerah di Indonesia, struktur umur penduduk Provinsi Jambi juga mengalami proses penuaan. Pada Tahun 1990 (SP 1990) proporsi penduduk lansia di Provinsi Jambi sebesar 4,00 persen menjadi 5,51 persen pada Tahun 2010 (SP 2010) dan meningkat lagi menjadi 6,39 persen pada Tahun 2015 (N.N, 2016b). Meningkatnya proporsi penduduk lansia di Provinsi Jambi dapat dimaknai sebagai keberhasilan pembangunan yang telah berhasil meningkatkan derajat kesehatan masyarkat di daerah ini. Meskipun demikian, dalam konteks sebagai modal pembangunan, peran lansia seharusnya berbeda dengan peran penduduk muda, mengingat kondisi fisik, mental dan sosialnya yang sudah banyak mengalami kemunduran. Idealnya lansia yang bekerja mempunyai pekerjaan yang sesuai dengan kondisi fisik dan mentalnya. Dalam rangka meningkatkan kesejahteraan dan peran lansia khususnya lansia bekerja perlu pemahaman dan pengetahuan tentang karakteristik pekerjaan lansia dan faktor yang mempengaruhi keterlibatannya dalam pasar kerja.

Berdasarkan hal tersebut, penelitian ini bertujuan untuk: 1) Menganalisis karakteristik individu dan pekerjaan dari lansia bekerja di Provinsi Jambi; 2) Menganalisis faktor-faktor sosial ekonomi yang mempengaruhi keterlibatan lansia dalam pasar kerja (bekerja).

\section{Metode Penelitian}

Data yang dipergunakan dalam penelitian ini bersumber dari "raw data" SUSENAS Tahun 2015 di Provinsi Jambi. Untuk menganalisis karakteristik individu dan pekerjaan dari lansia bekerja dilakukan secara deskriptif. Untuk menganalisis faktor-faktor yang mempengaruhi keterlibatan lansia dalam pasar kerja digunakan model regresi binary logistik dengan unit individu lansia dalam rumah tangga. Penggunaan model regresi binary logistik disebabkan variabel terikat (dependent variable) yang digunakan terdiri dari dua kategori yaitu terlibat atau tidaknya lansia dalam pasar kerja (bekerja). Sedangkan variabel independen karakteristik sosial ekonomi individu dan rumah tangga dari lansia.

Model regresi binary logistik tersebut diberikan sebagai berikut:

$$
\begin{aligned}
& g\left(x_{k i}\right)=\beta_{0}+\beta_{1} X_{1}+\beta_{2} X_{2}+\beta_{3 . D 1} X_{3 . D 1}+\beta_{3 . D 2} X_{3 . D 2}+\beta_{3 . D 3} X_{3 . D 3}+\beta_{.4} X_{4}+\beta_{.5} X_{5} \\
& \text { dimana: }+\beta_{.6} X_{6}+\beta_{.7} X_{7}+e \\
& \mathrm{~g}(\mathrm{xki})=\text { peluang lansia terlibat dalam bekerja }(0=\text { tidak bekerja; } 1=\text { bekerja }) \\
& \mathrm{X}_{1}=\text { Umur (tahun) }
\end{aligned}
$$


$\mathrm{X}_{2}=$ Jenis kelamin $(1=$ laki-laki; $0=$ perempuan $)$

$\mathrm{X}_{3}=$ Jenjang pendidikan formal (dengan kategori dasar tidak sekolah/tidak tamat SD),

$\mathrm{X}_{3 . \mathrm{D} 1} 1=\mathrm{SD} ; 0=$ lainnya $\mathrm{X}_{3 . \mathrm{D} 2} \quad 1=\mathrm{SLTP} ; \quad 0=$ lainnya

$\mathrm{X}_{3 . \mathrm{D} 3} \quad 1=$ SLTA dan PT; $0=$ lainnya

$\mathrm{X}_{4}=$ Status kawin $(1=$ kawin; 0 = lainnya $)$

$\mathrm{X}_{5}=$ Status dalam rumah tangga $(1=$ kepala keluarga; $0=$ lainnya $)$

$\mathrm{X}_{6}=$ Kondisi kesehatan (jumlah hari sakit dalam sebulan terakhir)

$\mathrm{X}_{7}=$ Wilayah desa/kota $(1=$ Desa; $0=$ Kota $)$

\section{Hasil Penelitian dan Pembahasan}

\section{Lansia bekerja menurut desa-kota}

Data Susenas 2015, menunjukkan besarnya proporsi penduduk lansia bekerja di Provinsi Jambi. Dari total penduduk lansia yang ada, hampir separuh (48,99 persen) adalah lansia dengan kegiatan utama bekerja. Selanjutnya berdasarkan sebaran desa/kota dapat dikemukakan bahwa lebih dari tiga perempatnya (77,32 persen) lansia bekerja di Provinsi Jambi berada di perdesaan, dan hanya 22,68 persen yang berada di perkotaan (Tabel 1).

Lebih banyaknya sebaran lansia yang bekerja di perdesaan dibandingkan di perkotaan selain disebabkan jumlah penduduk lansia yang pada dasarnya memang lebih banyak di perdesaan (karena jumlah penduduk juga lebih banyak di perdesaan), juga disebabkan oleh proporsi lansia bekerja di perdesaan yang lebih besar dibandingkan perkotaan. Dari total lansia di perdesaan, lebih separuh (54,60 persen) diantaranya adalah lansia dengan kegiatan utama bekerja. Sebaliknya, dari total lansia di perkotaan, hanya 36,27 persen diantaranya dengan kegiatan utama bekerja.

Tabel 1.

Lansia bekerja menurut desa-kota di Provinsi Jambi tahun 2015

\begin{tabular}{lcc}
\hline \multirow{2}{*}{ Desa-Kota } & \multicolumn{2}{c}{$\%$ Lansia Bekerja } \\
\cline { 2 - 3 } & $\begin{array}{c}\text { terhadap Total Lansia } \\
\text { Provinsi }\end{array}$ & $\begin{array}{c}\text { terhadap Total Lansia } \\
\text { Desa/Kota }\end{array}$ \\
\hline Perkotaan & 22,68 & 36,27 \\
Perdesaan & 77,32 & 54,60 \\
\hline Provinsi Jambi & 100,00 & 48,99 \\
\hline Sumber : diolah dari raw data Susenas Jambi 2015
\end{tabular}

\section{Karakteristik individu lansia bekerja}

Karakteristik individu dari lansia bekerja dalam hal ini dilihat dari jenis kelamin, umur, pendidikan, status kawin dan status dalam keluarga. Berdasarkan jenis kelamin dapat dikemukakan bahwa lebih sepertiga (70,80 persen) dari lansia bekerja di Provinsi Jambi adalah lansia laki-laki. Relatif lebih banyaknya lansia laki-laki yang bekerja selain menunjukkan adanya perbedaan dalam memperoleh kesempatan berpartisipasi dalam kegiatan ekonomi antara penduduk lansia laki-laki dengan perempuan, juga terkait dengan status lansia tersebut dalam keluarga. Umumnya ( 80,83 persen) lansia yang bekerja masih berada dalam ikatan perkawinan (berstatus kawin) dan 80,08 persen adalah meraka yang berstatus sebagai kepala keluarga (sebagaimana diketahui, umumnya kepala keluarga di Indonesia adalah laki-laki).

Fakta ini menunjukkan, meskipun sudah memasuki umur-umur yang sudah tidak lagi produktif, tetapi dengan besarnya tanggung jawab sebagai kepala rumah tangga, lansia harus tetap bekerja dalam rangka memenuhi kebutuhan hidup rumah tangganya. Bahkan, besarnya tanggung jawab 
tersebut menyebabkan lansia dengan umur yang relatif tua (70 tahun ke atas) "terpaksa" harus tetap bekerja. Data SUSENAS 2015 menunjukkan lebih 20 persen dari lansia yang bekerja di Provinsi Jambi adalah mereka yang berumur 70 tahun atau lebih (Tabel 2).

Selanjutnya berdasarkan pendidikan terlihat relatif rendahnya pendidikan dari lansia bekerja di Provinsi Jambi relatif rendah. Dari total lansia, hanya 9,68 persen yang memiliki pendidikan SLTA ke atas dan sebagian besar lainnya 80,03 persen berpendidikan tamat SD/tidak tamat SD bahkan tidak pernah sekolah. Lansia dengan pendidikan tinggi umumnya adalah mereka yang dulunya mempunyai pekerjaan dengan penghasilan yang relatif tinggi dan kebanyakan diantaranya juga memiliki jaminan hari tua/pensiun (terutama pada lansia yang dulunya bekerja pada sektor formal) sehingga pada masa tuanya mereka tidak perlu lagi bekerja karena sudah dapat mencukupi kebutuhan dirinya dan keluarga tanpa harus bekerja. Sebaliknya, lansia dengan pendidikan rendah, umumnya adalah mereka yang dulunya bekerja pada pekerjaan-pekerjaan dengan penghasilan terbatas (sehingga tidak mampu menabung/berinvestasi untuk hari tua) dan jarang memiliki jaminan hari tua/pensiun. Oleh karenanya, ketika memasuki usia tua tetap harus bekerja untuk memenuhi kebutuhan hidup.

Tabel 2.

Karakteristik individu lansia bekerja di Provinsi Jambi tahun 2015

\begin{tabular}{lr}
\hline \multicolumn{1}{c}{ Karakteristik } & $\%$ \\
\hline $\begin{array}{lr}\text { Jenis Kelamin } \\
\text { Laki-Laki }\end{array}$ & 70,80 \\
Perempuan & 29,20 \\
\hline Total & 100,00 \\
\hline Umur & 51,63 \\
$60-64$ & 27,69 \\
$65-69$ & 20,68 \\
$70+$ & 100,00 \\
\hline Total & \\
\hline Status dalam Keluarga & 80,08 \\
Kepala Rumah Tangga & 15,04 \\
Isteri/Suami & 4,14 \\
Orang tua/Mertua & 0,76 \\
Lainnya & 100,00 \\
\hline Total & 0,63 \\
\hline Status Kawin & 80,83 \\
Belum kawin & 18,54 \\
Kawin & 100,00 \\
Cerai hidup/mati & \\
\hline Total & 80,03 \\
\hline Pendidikan & 10,28 \\
SLTP & 7,15 \\
SLTA & 2,53 \\
\hline Perguruan Tinggi & 100,00 \\
\hline Total &
\end{tabular}

Sumber : diolah dari raw data Susenas Jambi 2015

\section{Karakteristik pekerjaan lansia}

Dalam rangka menggambarkan karakteristik pekerjaan lansia, dilihat dari lapangan pekerjaan, status pekerjaan dan jam kerja yang dicurahkan dalam pekerjaan guna pencaharian nafkah. Terkait dengan lapangan pekerjaan, terlihat bahwa sebagaimana halnya lapangan pekerjaan penduduk Provinsi jambi 
umumnya, lapangan pekerjaan dominan yang ditekuni oleh lansia juga pada lapangan pertanian. Lebih tiga perempat (75,56 persen) lansia di Provinsi Jambi bekerja pada lapangan usaha pertanian. Bagian terbesar kedua adalah perdagangan, hotel dan restoran yang mencapai 11,15 persen, sedangkan lapangan usaha-lapangan usaha lainnya relatif kecil (dengan proporsi kurang dari 10,00 persen) (Tabel 3). Banyak lansia yang bekerja pada lapangan pekerjaan pertanian dan perdagangan, karena umumnya kedua sektor tersebut tidak membutuhkan/ mensyaratkan tingkat pendidikan tertentu.

Tabel 3.

Karakteristik pekerjaan lansia bekerja di Provinsi Jambi tahun 2015

\begin{tabular}{|c|c|}
\hline Karakteristik & $\%$ \\
\hline \multicolumn{2}{|l|}{ Lapangan Pekerjaan } \\
\hline Pertanian & 75.56 \\
\hline Pertambangan dan penggalian & 1.13 \\
\hline Industri pengolahan & 1.88 \\
\hline Listrik dan gas & 0.13 \\
\hline Konstruksi/bangunan & 2.76 \\
\hline Perdagangan, hotel, dan rumah makan & 11.15 \\
\hline Transportasi, pergudangan, informasi, komunikasi & 1.50 \\
\hline Jasa & 5.26 \\
\hline Lainnya & 0.63 \\
\hline Total & 100,00 \\
\hline $\begin{array}{l}\text { Status Pekerjaan } \\
\text { Berusaha sendiri }\end{array}$ & 36.84 \\
\hline Berusaha dibantu buruh tidak tetap/tidak dibayar & 30.33 \\
\hline Berusaha dibantu buruh tetap/dibayar & 5.51 \\
\hline Buruh/karyawan/pegawai & 9.15 \\
\hline Pekerja bebas & 6.02 \\
\hline Pekerja keluarga/tidak dibayar & 12.16 \\
\hline Total & 100,00 \\
\hline \multicolumn{2}{|l|}{ Jam Kerja Seminggu } \\
\hline$<14$ & 12,91 \\
\hline $14-34$ & 42,98 \\
\hline $35-40$ & 14,16 \\
\hline$>40$ & 29,95 \\
\hline Total & 100,00 \\
\hline \multicolumn{2}{|l|}{ Hari Kerja Seminggu } \\
\hline $1-2$ & 5,64 \\
\hline $3-4$ & 22,06 \\
\hline $5-6$ & 40,98 \\
\hline 7 & 31,33 \\
\hline Total & 100,00 \\
\hline
\end{tabular}

Sumber : diolah dari raw data Susenas Jambi 2015

Selanjutnya, status pekerjaan menunjukkan posisi atau kedudukan seseorang dalam unit usaha/ kegiatannya. Status pekerjaan dibedakan atas 5 (lima) kelompok, yaitu: a) Berusaha sendiri, yaitu mereka yang bekerja atas resiko sendiri tanpa bantuan orang lain; b) Berusaha dengan dibantu oleh anggota rumah tangga/buruh tidak tetap, yaitu mereka yang dalam melakukan usahanya dibantu oleh anggota rumah tangga atau buruh tidak tetap; c) Berusaha dengan buruh tetap, yaitu mereka yang melakukan usahanya dengan mempekerjakan buruh tetap yang dibayar (sering pula diartikan sebagai majikan); d) Buruh/karyawan tetap, yaitu seseorang yang bekerja pada orang lain atau lembaga dengan menerima upah/gaji tetap baik berupa uang maupun barang; e) Buruh tidak tetap baik di pertanian ataupun non-pertanian, yaitu seseorang yang bekerja pada orang lain atau lembaga, tetapi pekerjaannya bersifat musiman/tidak tetap; f) Pekerja keluarga, yaitu anggota rumah tangga yang membantu usaha untuk memperoleh penghasilan/keuntungan yang dilakukan oleh salah seorang 
anggota rumah tangga atau bukan anggota rumah tangga tanpa mendapat upah/gaji.

Keenam status pekerjaan tersebut dapat dikelompokkan lagi atas pekerja yang bekerja di sektor informal dan sektor formal. Status (a), (b), (e) dan (f) merupakan pekerja di sektor informal, sedangkan status (c) dan (d) merupakan pekerja sektor formal. Berdasarkan pengelompokan ini terlihat bahwa, umumnya (85,34 persen) dari lansia berada pada pekerjaan-pekerjaan informal. Hanya 14,66 persen yang berstatus formal, yaitu mereka yang berusaha dibantu buruh tetap/dibayar (5,51 persen) dan sebagai buruh/karyawan/ pegawai $(9,15$ persen).

Ditelusuri lebih jauh berdasarkan status pekerjaan terlihat bahwa umumnya lansia berstatus bekerja sendiri dan berusaha dibantu anggota rumah tangga/buruh tidak tetap. Proporsi lansia yang berada pada kedua status pekerjaan ini masing-masingnya mencapai 36,84 persen dan 30,33 persen. Dalam bentuk konkritnya, jika dikaitkan dengan lapangan pekerjaan sebagaimana yang telah dikemukakan sebelumnya, maka dapat diartikan bahwa lebih sepertiga dari lansia di Provinsi Jambi adalah petanipetani kecil, pekebun-pekebun kecil dan nelayan-nelayan kecil.

Berbagai hasil penelitian menunjukkan bahwa rendahnya pendapatan pekerja pada kedua status ini selain disebabkan oleh rendahnya produktivitas kerja mereka (baik karena faktor kemampuan fisik maupunkarena faktorketerampilan), juga disebabkan olehminimnya asetberusaha yang dimiliki dalam rangka mendukung peningkatan produktivitas kerja. Oleh karena itu, dalam rangka meningkatkan pendapatan pekerja pada kedua status tersebut, perluasan akses untuk mendapatkan permodalan dalam meningkatkan aset berusaha merupakan "core" kebijakan yang harus diterapkan. Tanpa adanya peningkatan aset berusaha, upaya-upaya yang dilakukan dalam peningkatan keterampilan dari petani kecil, pekebun kecil maupun nelayan kecil tidak akan berhasil dalam mencapai sasaran peningkatan pendapatan mereka. Terkait dengan jam kerja, klasifikasi BPS menyatakan seseorang dikatakan bekerja penuh jika jam kerja perminggu adalah 35 jam atau lebih. Dikatakan setengah pengangguran biasa jika jam kerja antara 14-34 jam seminggu dan setengah pengangguran kritis jika jam kerja kurang dari 14 jam semingggu. Selanjutnya, berdasarkan UU No.13 Tahun 2003 mengenai ketenagakerjaan, dinyatakan bahwa waktu kerja normal adalah sampai dengan 40 jam seminggu (Amril et al. 2015).

Berdasarkan hal tesebut, meskipun terlihat lebih separuh (55,89 persen) dari lansia terkategori setengah penganggur (kritis dan biasa) atau bekerja di bawah jam kerja normal, tetapi juga terdapat lansia dengan jam kerja melebihi jam kerja normal (di atas 40 jam seminggu) dengan proporsi yang cukup besar mencapai 29,95 persen. Fakta ini menunjukkan pada dasarnya ada dua kategori pekerja lansia dari sisi jam kerja. Pertama, lansia yang bekerja hanya sekedar untuk menambah penghasilan keluarga atau sekedar mengisi waktu luang (sehingga bekerja dengan jam yang tidak terlalu panjang). Kedua, lansia yang bekerja sebagai pencari nafkah utama (kepala keluarga), karena bekerja pada lapangan kerja dengan produktivitas rendah, maka perpanjangan alokasi waktu kerja merupakan strategi bertahan hidup yang diambil oleh lansia tersebut. Pola ini juga terlihat nyata berdasarkan curahan hari kerja. Terdapat lansia dengan hari kerja hanya 1-2 dan 3-4 hari seminggu (dengan proporsi masing-masingnya 5,64 persen dan 22,06 persen), tetapi juga terdapat hampir sepertiga (31,33 persen) diantara lansia yang bekerja setiap hari (tujuh hari dalam seminggu).

\section{Faktor-faktor sosial ekonomi yang mempengaruhi keterlibatan lansia dalam pasar kerja}

\section{Uji overall model fit}

Uji Overall Model Fit dari model tersebut diberikan pada Tabel 4. Berdasarkan Omnibus Test of Model Coefficients didapatkan nilai statistik Chi_Square sebesar 724,290 dengan probabilitas signifikansi $(\mathrm{p})=0.000$. Dengan demikian dapat disimpulkan bahwa peubah bebas dalam model secara bersama-bersama mempengaruhi keputusan dan perilaku lansia untuk terlibat atau tidak terlibat dalam pasar kerja. Berdasarkan uji Hosmer dan Lemeshow didapatkan nilai Chi-Square sebesar 7,665 dengan nilai p sebesar 0,467. Karena Chi_Square tidak signifikan ( $p>0,05)$, maka dapat disimpulkan probabilitas yang diprediksi sesuai dengan probabilitas yang diobservasi. Dengan 
kata lain tidak ada perbedaan antara model dengan data sehingga model dapat dikatakan fit.

Tabel 4.

Uji overall model fit untuk model lansia bekerja

\begin{tabular}{lrrr}
\hline & Chi-square & df & Sig. \\
\hline Omnibus Test of Model Coefficients & 655,075 & 9 & 0,000 \\
Hosmer and Lemeshow Test & 11.997 & 8 & 0.151 \\
\hline
\end{tabular}

Selanjutnya dari tabel 5, seberapa baik model mengelompokkan kasus ke dalam dua kelompok baik yang bekerja maupun tidak bekerja. Keakuratan prediksi secara keseluruhan sebesar 77,6 persen sedangkan keakuratan prediksi lansia yang tidak bekerja sebesar 77,5 persen dan lansia bekerja 77,7 persen. Dengan kata lain, keakuratan model ini dalam memprediksi probabilita bekerja dan tidak bekerjanya lansia adalah relatif sama.

Tabel 5.

Klasifikasi 2 × 2 untuk model lansia bekerja

\begin{tabular}{llcrr}
\hline & \multicolumn{3}{c}{ Prediksi } \\
\cline { 3 - 4 } Observasi & \multicolumn{2}{c}{ Kategori } & \multirow{2}{*}{$\begin{array}{c}\text { Persentase } \\
\text { Benar }\end{array}$} \\
\cline { 3 - 4 } & & Tidak Bekeria & Bekerja & \\
\hline Kategori & Tidak Bekerja & 620 & 211 & 74,6 \\
& Bekerja & 195 & 603 & 75,6 \\
Persentase Keseluruhan & & & 75,1 \\
\hline
\end{tabular}

\section{Estimasi parameter dan uji parsial}

Estimasi parameter dan uji parsial dalam model binari logit untuk lansia bekerja diberikan pada Tabel 6. Berdasarkan hasil estimasi memperlihatkan bahwa umur $\left(\mathrm{X}_{1}\right)$ berpengaruh signifikan negatif terhadap probabilitas lansia bekerja. Semakin tua umur maka akan semakin menurunkan probabilitas lansia untuk bekerja. Mengamati odds ratio dapat dikemukakan bahwa lansia yang berumur lebih tua satu tahun memiliki probabilitas 0,891 kali (lebih rendah) untuk bekerja dibandingkan dengan lansia yang berumur lebih muda. Hal ini dikarenakan semakin tua umur seseorang, kemampuan beraktivitas dan bekerja akan semakin menurun.

Jenis kelamin $\left(\mathrm{X}_{2}\right)$ juga memperlihatkan pengaruh yang signifikan. Mengamati odd ratio terlihat bahwa lansia laki-laki memiliki probabilita 2,592 kali (lebih tinggi) untuk bekerja dibandingkan lansia perempuan. Lebih tingginya probabilita lansia laki-laki disebabkan tanggungjawab lansia lakilaki yang masih besar sebagai kepala keluarga.

Terkait dengan pendidikan (dengan kategori dasar adalah lansia tidak sekolah/tidak tamat SD), dapat dikemukakan tidak terdapat perbedaan probabilitas bekerja antara lansia yang berpendidikan $\mathrm{SD}\left(\mathrm{X}_{3}\right.$. ${ }_{\text {D1 }}$ ) dengan yang lansia yang tidak sekolah/tidak tamat SD. Hal ini ditunjukkan oleh koefisien dalam model yang tidak signifikan. Namun demikian, koefisien pada kelompok pendidikan SLTP $\left(\mathrm{X}_{3 . \mathrm{D} 2}\right)$ dan SLTA ke atas $\left(\mathrm{X}_{3 . \mathrm{D} 3}\right)$ signifikan negatif. Ini menunjukkan bahwa lansia dengan pendidikan SLTP dan SLTA ke atas memiliki probabilitas yang lebih rendah untuk bekerja dibandingkan dengan lansia tidak sekolah/tidak tamat SD. Dari nilai odds ratio memperlihatkan bahwa lansia yang berpendidikan SLTP memiliki probabilitas 0,577 kali (lebih rendah) untuk bekerja dibandingkan lansia yang tidak sekolah/tidak tamat SD. Probabilitas ini terlihat lebih rendah lagi pada lansia dengan pendidikan SLTA ke atas, dengan nilai probabilitas (odds ratio) yang sebesar 0,310. 
Tabel 6.

Estimasi parameter model lansia bekerja

\begin{tabular}{|c|c|c|c|c|c|c|c|}
\hline Variabel & B & S.E. & Wald & df & Siq & $\begin{array}{l}\text { Odds } \\
\text { ratio }\end{array}$ & Keterangan \\
\hline $\mathrm{X} 1$ &,- 107 &, 010 & 107,095 & 1 &, 000 & ,898 & Umur \\
\hline $\mathrm{X} 2$ & ,948 & ,194 & 23,894 & 1 &, 000 & 2,580 & Jenis Kelamin \\
\hline $\mathrm{X} 3$ & & & 35,253 & 3 &, 000 & & Pendidikan \\
\hline X3.D1 &,- 111 & , 155 &, 517 & 1 & ,472 & ,895 & SD \\
\hline X3.D2 &,- 731 & ,242 & 9,170 & 1 &, 002 & ,481 & SLTP \\
\hline X3.D3 & $-1,296$ & ,231 & 31,349 & 1 & ,000 & ,274 & SLTA dan PT \\
\hline$X 4$ & 1,100 & ,163 & 45,690 & 1 &, 000 & 3,006 & Status Kawin \\
\hline$\times 5$ & 1,212 & 180 & 45,515 & 1 &, 000 & 3,361 & Status dlm Keluarga \\
\hline $\begin{array}{l}X 6 \\
\times 8\end{array}$ & $\begin{array}{l}-, 092 \\
768\end{array}$ & $\begin{array}{l}012 \\
143\end{array}$ & $\begin{array}{l}59,100 \\
28822\end{array}$ & $\begin{array}{l}1 \\
1\end{array}$ & , 000 & , 912 & Jumlah hari sakit \\
\hline Konstanta & 5,149 & ,716 & 51,666 & 1 & , & 172,304 & \\
\hline
\end{tabular}

Status kawin $\left(\mathrm{X}_{4}\right)$ juga memperlihatkan pengaruh yang signifikan. Mengamati odd ratio terlihat bahwa lansia yang berstatus kawin memiliki probabilita 3,048 kali (lebih tinggi) untuk bekerja dibandingkan lansia dengan status lainnya (belum kawin, cerai hidup dan cerai mati). Sejalan dengan hal tersebut, status dalam keluarga juga menunjukkan pengaruh yang signifikan. Lansia yang berstatus sebagai kepala keluarga memiliki probabilita 3,604 kali (lebih tinggi) untuk bekerja dibandingkan lansia dengan status lainnya (isteri/suami, orang tua/mertua, dan lainnya). Kedua fakta ini menunjukkan bahwa pada dasarnya keterlibatan lansia untuk bekerja disebabkan masih tingginya beban lansia dalam memenuhi kebutuhan hidup keluarga.

Selain faktor kebutuhan keluarga, faktor kesehatan juga menjadi faktor penentu keterlibatan lansia dalam pasar kerja. Hal ini terlihat dari kenyataan signifikannya variabel jumlah hari sakit $\left(\mathrm{X}_{6}\right)$ dengan arah negatif. Mengamati odds ratio, dapat dikemukakan bahwa lansia dengan jumlah hari sakit lebih banyak satu hari memiliki probabilitas 0,907 kali (lebih rendah) untuk bekerja dibandingkan dengan lansia dengan jumlah hari sakit yang lebih sedikit. Selanjutnya dalam konteks desa-kota, hasil penelitian ini juga menunjukkan terdapat perbedaan probabilita untuk bekerja yang signifikan antara lansia yang ada di perkotaan dengan perdesaan. Mengamati odds ratio variabel $\mathrm{X}_{7}$ terlihat bahwa lansia di perdesaan memiliki probabilita 1,950 kali (lebih tinggi) untuk bekerja dibandingkan lansia yang ada diperkotaan. Lebih besarnya probabilita bekerjanya lansia di perdesaan diduga disebabkan oleh dua hal. Pertama, tingkat kesejahteraan lansia dan keluarganya yang lebih rendah di perdesaan (baik disebabkan tidak adanya jaminan hari tua/pensiun maupun tidak adanya tabungan/investasi untuk masa tua) dibandingkan perkotaan yang menyebabkan lansia "terpaksa" harus tetap bekerja untuk mencukupi kebutuhan hidup keluarga (Nilakusmawati 2014). Kedua, relatif lebih banyaknya kesempatan kerja yang lebih mudah dimasuki oleh lansia di perdesaan karena tidak membutuhkan persyaratan pendidikan/keterampilan tertentu di perdesaan (terutama di sektor pertanian) dibandingkan kesempatan kerja di perkotaan.

\section{Simpulan}

Proporsi lansia yang masih terlibat dalam pasar kerja di Provinsi Jambi masih relatif besar. Dari total lansia yang ada di Provinsi Jambi pada Tahun 2015, hampir separuhnya (48,99 persen) adalah lansia dengan kegiatan utama bekerja. Karakteristik lansia bekerja ditandai oleh: a) Lebih dominan di perdesaan dibandingkan di perkotaan; b) Di dominasi oleh lansia laki-laki; c) umumnya berstatus kepala keluarga dengan status kawin; d) umumnya berpendidikan SD dan tidak sekolah/tidak tamat $\mathrm{SD}$; e) sebagian besar bekerja pada lapangan usaha pertanian dan perdagangan dengan jam kerja yang relatif panjang.

Terdapat berbagai faktor sosial ekonomi yang berpengaruh nyata terhadap keterlibatan lansia bekerja di Provinsi Jambi. Faktor-faktor tersebut adalah umur, jenis kelamin, pendidikan, status kawin, 
status dalam keluarga dan kondisi kesehatan. Penelitian ini juga menemukan perbedaan proporsi keterlibatan lansia bekerja antar desa-kota.

\section{Daftar Pustaka}

Affandi M (2009) Faktor-faktor yang mempengaruhi penduduk lanjut usia memilih untuk bekerja. Journal of Indonesian Applied Economics 3(2): 99-110.

Amril, Erfit \& Yulmardi (2015) Dinamika ekonomi dan peluang kerja rumah tangga perkebunan rakyat di Kabupaten Tanjung Jabung Barat. Jurnal Perspektif Pembiayaan dan Pembangunan Daerah 3(1): 1-10.

Fitri \& Basri (2012) Faktor -faktor yang mempengaruhi lanjut usia bekerja di kelurahan simpang baru kecamatan tampan kota pekanbaru.[Diakses pada 3 Maret 2015]. http//:repository.unri. ac.id.

Kartika NPRD \& Sudibia IK (2014) Pengaruh variabel sosial demografi dan sosial ekonomi terhadap partisipasi kerja penduduk lanjut usia. E-Jurnal EP UNUD 3 (6): 247-256.

N.N (2013) Gambaran Kesehatan Lanjut Usia di Indonesia. Buletin Jendela Data dan Informasi Kesehatan. Jakarta: Pusat Data dan Informasi Kementerian Kesehatan RI

N.N (2011) Angka Kematian Bayi dan Angka Harapan Hidup Penduduk Indonesia Hasil Sensus Penduduk 2010. Jakarta: BPS

N.N (2014) Angka harapan hidup penduduk beberapa negara, 1995-2015. [Diakses pada 5 Oktober 2015]. https://www.bps.go.id/linkTabelStatis/view/id/1517.

N.N (2016a) Profil Penduduk Indonesia Hasil SUPAS 2015. Jakarta; BPS

N.N (2016b) Statistik Penduduk Lanjut Usia 2015. Jakarta; BPS

Nilakusmawati DPE (2014) Model status jaminan sosial lansia di perkotaan Provinsi Bali. Seminar Nasional Sains \& Teknologi LPPM Universitas Udayana.

Susilawati M, Nilakusmawati DPE \& Rimbawan ND (2014) Determinan dari status pekerjaan berdasarkan karakteristik sosial ekonomi lanjut usia di perdesaan Provinsi Bali. Seminar Nasional Sains dan Teknologi. Denpasar-Bali. 18-19 September 2014.

Wirakartakusumah MD \& Evi HA (1994) Aging in Indonesia: Demographic Characteristic. Departemen of Geography University of Adelaide. 